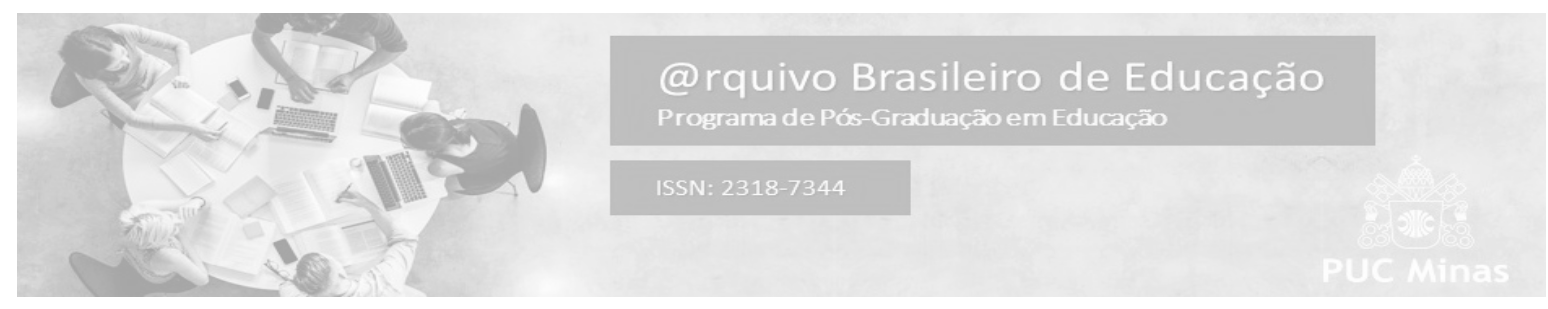

\title{
UM MAPEAMENTO QUANTITATIVO DO CAMPO CURRICULAR BRASILEIRO ENTRE 2006-2016
}

\section{A QUANTITATIVE MAPPING OF THE BRAZILIAN CURRICULAR FIELD BETWEEN 2006-2016}

Márden de Pádua Ribeiro Bernoulli Sistema de Ensino

\section{RESUMO}

O presente artigo é fruto de um recorte das conclusões de uma tese de doutorado em Educação que se dedicou a mapear a produção de artigos científicos no campo curricular brasileiro na década de 2006-2016. O critério do presente texto foi sistematizar os dados quantitativos coletados e descrevê-los de forma analítica e problematizadora, suscitando reflexões ao campo. A pesquisa é quantitativa, bibliográfica e utilizou a análise de conteúdo como técnica para organização dos dados obtidos. Foram compilados 226 artigos cuja temática focalizava a educação básica, em meio a cinco periódicos de prestígio no campo curricular brasileiro: Currículo sem Fronteiras, e-Curriculum, Espaço do Currículo, Teias e Educação e Realidade.

Palavras-chave: Campo curricular; Artigos científicos; Pesquisa quantitativa

\section{ABSTRACT}

This article is the fruit of a cut of the conclusions of a doctoral thesis in Education that was dedicated to map the production of scientific articles in the Brazilian curricular field in the decade of 2006-2016. The criterion of the present text was to systematize the quantitative data collected and to describe them in an analytical and problematizing way, provoking reflections to the field. The research is quantitative, bibliographical and used content analysis as a technique for organizing the obtained data. A total of 226 articles were compiled focusing on basic education, among five prestigious journals in the Brazilian curricular field: Currículo sem Fronteiras, e-Curriculum, Espaço do Currículo, Teias and Educação e Realidade.

Keywords: Curricular field; Scientific articles; Quantitative research 


\section{INTRODUÇÃO}

Currículo é um campo de disputa e tal assertiva já pode ser considerada premissa básica no campo curricular brasileiro. Teóricos de correntes distintas dão novas interpretações a essa disputa, mas não a negam. Sejam disputas ideológicas, por hegemonias, por poder, por poder-saber, sejam disputas entre enunciados discursivos, fato é que estudar o currículo é se embrenhar no âmbito da disputa como marca central de suas teorias.

O presente artigo é fruto de minha tese de doutorado em que busquei conhecer melhor essa disputa, analisando a produção que se desenvolve no campo do currículo. Tal disputa se dá via discurso, via conflitos de interesses no campo, disputas por espaços de saber, de poder, que decorrem de escolhas e exclusões de determinados aportes teóricos em razão de interesses e objetivos que se preponderam em detrimento de outros. Em suma, a produção acadêmica no campo do currículo é um campo em disputa.

Seguimos os rastros metodológicos de uma pesquisa ampla feita por Lopes e Macedo (2006), em que as autoras mapearam a produção de currículo, tendo por base teses, dissertações e artigos em periódicos selecionados no período de 1996 a 2002. Tal pesquisa nos serviu de ancoragem, na medida em que possibilitou um ponto de partida, que buscamos acolher em diversos momentos e estabelecer pequenas diferenças em outros, de modo que nossos objetivos venham a ser cumpridos.

Adotamos, portanto, como recortes necessários à pesquisa o estabelecimento de três critérios:

A) Temporal: mapeamento de artigos em meio ao período entre 2006-2016

B) Produção: foram mapeados artigos científicos somente

C) Tema: foram filtrados artigos focalizados na educação básica.

Assim, o objetivo deste artigo é descrever e analisar os resultados quantitativos deste mapeamento, no tocante aos referenciais bibliográficos de maior ocorrência, à distribuição regional das produções e dos periódicos, bem como as instituições que mais lograram produção ao campo. 
Entendemos, desse modo, que socializar este recorte da tese para a comunidade acadêmica é de especial relevância no sentido de possibilitar aos interessados no campo curricular, uma reflexão acerca de aspetos gerais da produção de conhecimentos. A pesquisa, de caráter inédito, fornece dados interessantes que certamente provocam inquietações fundamentais para o desenrolar do campo.

\section{APROFUNDAMENTO METODOLÓGICO}

É relevante aprofundarmos como se deu esse levantamento, sob que premissas teórico-metodológicas e quais etapas foram se sucedendo para a sistematização das produções. Na esteira da pesquisa de Lopes e Macedo (2006), buscamos, como já dito, focalizar somente os artigos que priorizavam estudos calcados na educação básica. Dentro desse recorte amplo, procuramos estabelecer categorias temáticas que nos permitiram sistematizar de forma mais precisa a compilação dos artigos. Foram considerados como produções pertencentes ao recorte temático da presente pesquisa, estudos que compreendem as seguintes categorias temáticas:

(a) Teoria curricular: estudos que focalizam um aprofundamento teórico sobre currículo, sem a presença de pesquisa de campo, perpassando pelas dimensões da cultura, da diferença, da identidade, do poder, da política, da linguagem, etc. Estudos que propõem ressignificações ao campo curricular através de novas formas de pensar a pesquisa em currículo, as vertentes teóricas, reflexões a respeito da relação conceitual entre o currículo e determinados conceitos do campo da Filosofia, Sociologia e Antropologia.

(b) Materialização das disciplinas escolares da educação básica na sala de aula: pesquisas envolvendo a articulação de componentes curriculares contextualizados na prática escolar da educação básica. Trabalhos que priorizaram o componente curricular. Eliminamos estudos cujo enfoque central foi somente na história da educação, na história das disciplinas escolares, ou na história do currículo propriamente dito.

(c) Ênfase nos conhecimentos: estudos cujo foco se deu na análise acerca do conhecimento e conhecimento escolar, envolvendo componentes curriculares, 
incluindo ensino das diferentes áreas, análise de ensino disciplinar, processos de transformação dos saberes para fins de ensino; conhecimentos e saberes produzidos no cotidiano escolar; contextualização e recontextualização dos conhecimentos escolares; seleção/exclusão de determinados conhecimentos; Foram descartadas as pesquisas centradas apenas em metodologias de ensino.

(d) Organização curricular na educação básica: estudos que focalizam a sequência dos conteúdos, do currículo integrado (interdisciplinaridade, transdisciplinaridade, projetos, temas geradores, multisseriação), a organização em ciclos de formação. Salientando que foram acolhidos os estudos que associaram essa organização a pesquisas oriundas da educação básica, conforme recorte estabelecido.

(e) Prática curricular: predominância das práticas curriculares envolvendo o cotidiano escolar, desde que as priorizando especificamente o currículo;

(f) Políticas de currículo: estudos que envolvem a percepção das políticas de currículo e seus processos de recontextualização ou tradução, na educação básica. Excluímos trabalhos voltados a analisar apenas diretrizes e/ou parâmetros e/ou propostas curriculares oficiais específicas por si só. Exceção aos trabalhos que se pautam por analisar a Base Nacional Comum Curricular. Estes trabalhos entraram como critério de análise.

(g) Estudos da Diferença/Identidade: pesquisas que focalizam questões relativas a raça/etnia, gênero, sexualidade, seja a partir de um enfoque associado aos estudos culturais, às teorias pós-estruturalistas seja a partir de outros princípios teóricos; trabalhos que buscaram discutir a relação da diferença com a identidade.

Os critérios acima, utilizados como categorias temáticas, portanto, serviram como baliza para filtrar os artigos dos periódicos selecionados. Para interpretar e categorizar os dados a pesquisa tomou como perspectiva a análise de conteúdo (BARDIN, 2011), no sentido de possibilitar a extração de significados dos textos. De acordo com Chizzotti (2008, p.113), a análise de conteúdo "visa decompor as unidades léxicas ou temáticas de um texto, codificadas sobre algumas categorias, 
compostas por indicadores que permitam uma enumeração das unidades, e a partir disso, estabelecer inferências generalizadoras".

A análise de conteúdo possibilita, portanto, a inferência do que está por trás dos conteúdos manifestos, indo além das aparências do que está sendo comunicado. Segundo Bardin (2011, p.128), a análise de conteúdo possui três fases: a primeira seria uma análise prévia, que consiste em escolher os documentos que serão submetidos à análise, no intuito de formular hipóteses e objetivos visando "a elaboração de indicadores que darão sustentação à interpretação final". A segunda fase corresponde a exploração do material coletado, com o intuito de codificar e enumerar os dados coletados categorizando-os. E finalmente, a última fase referese ao tratamento dos resultados obtidos e sua interpretação, sendo tarefa do pesquisador nesse momento, interpretar e apontar as inferências com base nas categorias levantadas na fase anterior. Assim, produzir uma inferência é condição essencial em análises de conteúdo.

No que concerne aos nossos periódicos escolhidos, o recorte consistiu em abarcar revistas que atendiam alguns critérios de escolha semelhantes àqueles utilizados por Lopes e Macedo (2006). As autoras em um primeiro momento fizeram uma consulta a respeito dos principais periódicos do Brasil àquela época. Posteriormente, fizeram uma pesquisa, através dos currículos Lattes, a respeito da produção de pesquisadores ligados aos principais núcleos de pesquisa em currículo do Brasil. Para tal, buscaram informações disponíveis na página do CNPq na Internet: "O levantamento teve por objetivo verificar os periódicos em que esses pesquisadores mais veiculavam seus produtos de pesquisa” (LOPES; MACEDO, 2006, p. 20). Assim, articulando esse levantamento com as revistas em que esses pesquisadores mais produziam, as autoras chegaram a uma lista dos cinco periódicos com maior representatividade àquela época.

No nosso caso, adotamos procedimento semelhante: em um primeiro momento, utilizamos a plataforma Sucupira ${ }^{1}$ para verificação do Qualis dos periódicos brasileiros (não consideramos periódicos estrangeiros). Procuramos

${ }^{1}$ https://sucupira.capes.gov.br/sucupira/public/consultas/coleta/veiculoPublicacaoQualis/listaCon sultaGeralPeriodicos.jsf 
delimitar como extrato mínimo os periódicos avaliados em B3. A partir desse filtro, buscamos identificar os pesquisadores com maior representação em grupos de pesquisa em currículo no país, com base nos dados provenientes do $\mathrm{CNPq}$, articulando aos maiores índices de citação que possuem, com base em citações compiladas do Google Acadêmico.

Nos currículos Lattes desses pesquisadores, foram consultadas suas produções específicas do campo do currículo entre 2006 e 2016. Utilizamos como filtro os pesquisadores que publicaram ao menos cinco artigos específicos ao campo curricular no recorte temporal delimitado; somamos a este critério, a relevância dos pesquisadores através dos índices de citação presentes no Google Acadêmico e articulamos isso às suas vinculações a grupos de pesquisa de programas de pós-graduação que possuam sólida legitimidade no campo curricular. Para nos embasarmos em relação a essa solidez dos programas, comparamos com os programas filtrados na pesquisa de Lopes e Macedo (2006) e buscamos suas avaliações na Coordenação de Aperfeiçoamento de Pessoal de Nível Superior (CAPES).

Compilamos os periódicos em que esses pesquisadores mais publicaram, considerando o extrato B3 selecionado como filtro. Dessa forma, ao chegarmos na listagem dos 17 pesquisadores e ao levantar em quais periódicos mais publicaram, chegamos a uma listagem mais segura dos cinco periódicos de maior relevância para o campo curricular: Currículo sem Fronteiras, E-Curriculum, Teias, Espaço do Currículo e Educação e Realidade. o gráfico abaixo ilustra a incidência de artigos por periódico, no espaço temporal de 2006-2016, no âmbito dos 17 pesquisadores selecionados.

Gráfico 1: Produção dos 17 pesquisadores selecionados 


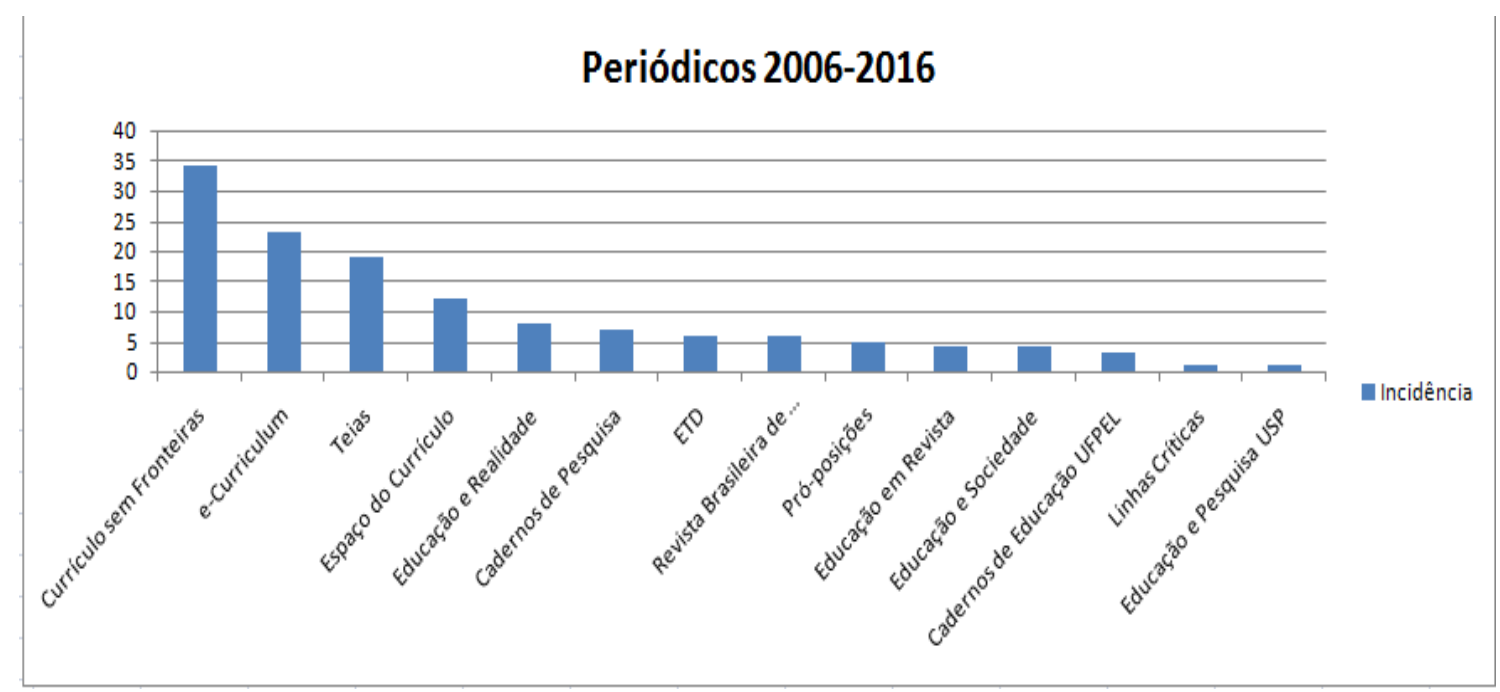

Fonte: dados da pesquisa (2018)

Para realizar uma pesquisa de caráter bibliográfico, segundo Gil (2002), é preciso seguir uma ordem lógica e racional de passos, que permitem a organização do estudo. Nesse sentido, é crucial que o trabalho se inicie com um problema que esteja inquietando o pesquisador e, ao final, produza-se um produto, ainda que provisório, mas que seja capaz de dar origem a novas interrogações e, portanto, a novos estudos.

Gil (2002) ressalta ainda que a pesquisa bibliográfica envolve uma série de procedimentos como identificar, localizar e obter documentos pertinentes ao assunto, levantando a bibliografia básica. Dessa forma, é possível perceber que a pesquisa bibliográfica é um procedimento de extrema relevância, pois traz as contribuições de diferentes autores sobre o tema estudado.

Sendo assim, a utilização da pesquisa bibliográfica foi muito pertinente para a fundamentação e para a interpretação dos elementos levantados neste trabalho. Os instrumentos de pesquisa aqui utilizados possibilitaram alcançar os objetivos propostos. Pois é através da pesquisa científica que o investigador obtém as respostas para suas indagações e automaticamente formula novas perguntas sobre a temática pesquisada.

Passemos então à análise quantitativa das produções, visando cumprir os objetivos do presente artigo. 


\section{OS ARTIGOS COMPILAdOS NOS CINCO PERIÓdICOS: ANÁlISE QUANTITATIVA}

Esta análise de cunho mais geral possibilitará a identificação da concentração regional dos autores dos artigos, de seus vínculos profissionais, das incidências das publicações a cada ano, das referências bibliográficas mais utilizadas e dos periódicos que mais forneceram artigos dentro do recorte temático estabelecido

O quadro abaixo apresenta o número de artigos selecionados por periódico:

\begin{tabular}{|l|l|}
\hline \multicolumn{2}{|c|}{ Quadro 2 - Periódicos: quantidade de artigos } \\
\hline PERIÓDICOS & $\begin{array}{l}\text { QUANTIDADE } \\
\text { SELECIONADOS }\end{array}$ \\
\hline Currículo sem Fronteiras & 76 \\
\hline Espaço do Currículo & 68 \\
\hline e-Curriculum & 42 \\
\hline Teias & 29 \\
\hline Educação e Realidade & 11 \\
\hline Total de artigos compilados & 226 \\
\hline
\end{tabular}

Fonte: dados da pesquisa, (2018).

Vale relembrar que adotamos como recorte temático aqueles artigos focados em estudos voltados para a educação básica; deste modo, num total de 226 artigos compilados entre 2006-2016, foi possível perceber uma predominância considerável dos periódicos Currículo sem Fronteiras e Espaço do Currículo perante os demais. $\mathrm{O}$ dado não surpreende na medida em que são revistas mais voltadas para a teoria curricular propriamente dita, o mesmo ocorre com o periódico e-Curriculum. Os dois últimos são mais diversificados em relação às suas temáticas.

Num total de 226 artigos compilados, 52 correspondem às produções dos dezessete curriculistas dominantes do campo, o que equivale a $23 \%$ da produção total analisada, certamente um número considerável, que corrobora a posição 
simbólica de prestígio destes curriculistas, conferindo-lhes uma espécie de distinção, em termos bourdieusianos.

Se $23 \%$ do total de artigos compilados corresponde aos pesquisadores dominantes, evidentemente que o restante das produções é dividido entre um imenso número de pesquisadores que nos últimos dez anos, publicaram seus artigos nos cinco periódicos aqui delimitados, entendidos por nós como os periódicos centrais ao campo do currículo. Sendo assim, é importante trazermos aqui alguns dados quantitativos que nos permitirão uma fotografia mais apurada dos aspectos gerais dessa produção.

O gráfico abaixo ilustra a incidência das produções em cada periódico, nos últimos dez anos:

Gráfico 2: Incidência das produções por periódico (2006-2016)

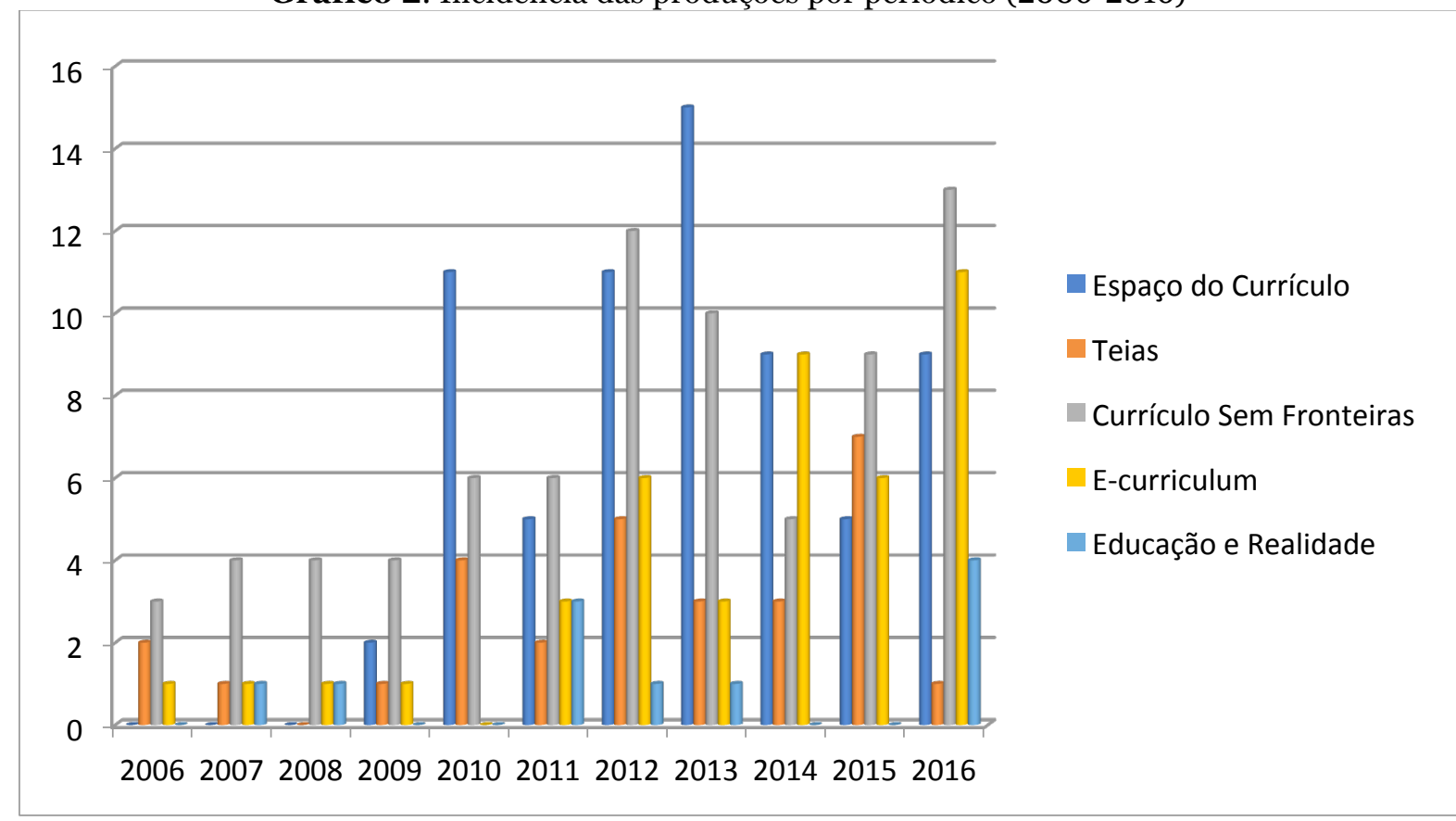

Fonte: dados da pesquisa (2018).

Podemos perceber que a segunda metade da década pesquisada traz um aumento significativo das produções, o que significa concluir que dentro da temática delimitada - estudos que focalizam a educação básica - há um predomínio de estudos que se voltam para esta abordagem. No entanto, para nós, a 
principal explicação desse aumento decorre da expansão das edições dos periódicos a partir da segunda metade da década pesquisada. Todos os cinco periódicos, a partir de 2010, passaram a aumentar suas edições, o que obviamente acaba por contribuir para o aumento das produções ampliando assim a possibilidade de coleta dos artigos compilados.

O periódico Espaço do Currículo mantinha média de duas edições por ano até 2011, e posteriormente passou a se organizar a partir de três edições. O periódico Teias foi aumentando progressivamente suas edições: no binômio 20062007 apresentou apenas uma edição. No binômio seguinte, ampliou para duas edições-ano. No binômio 2010-2011, passou para três edições ao ano e posteriormente, até 2016, chegou a quatro edições-ano. No entanto, esse aumento gradativo do número de edições não necessariamente significou aumento respectivo dos artigos compilados, pois algumas edições não abarcavam a temática aqui delimitada.

O período Currículo sem Fronteiras, como já dito, corresponde ao periódico que logrou o maior número de produções compiladas. No gráfico acima, é possível perceber também que a partir de 2010 há um aumento no número de artigos compilados por nós. De 2006 a 2011, este periódico se organizava através de duas edições anuais. De 2012 a 2016 as edições passaram para três por ano; um leve aumento, que significou impactou na incidência de produções compiladas.

De forma semelhante aos demais periódicos, no caso da revista $e$ Curriculum também foi possível notar um aumento das produções a partir da segunda metade da década pesquisada. Também de forma parecida com os demais, este periódico apresentou um aumento gradativo em suas edições. Passando de duas por ano entre 2006-2010; três por ano entre 2011-2014; e quatro por ano de 2014 a 2016.

$\mathrm{O}$ periódico Educação e Realidade correspondeu à revista com menor incidência de artigos filtrados, e o pequeno número se mostrou relativamente estável mesmo diante do aumento progressivo das edições anuais. A revista que começou em 2006 com duas edições por ano e em 2016 chegou a apresentar cinco edições por ano, mais do que o dobro num intervalo de uma década, ainda assim, 
este significativo aumento não se traduziu proporcionalmente no aumento das produções em currículo cuja temática focalizava a educação básica. É curioso, no caso deste periódico, constatar que na pesquisa realizada por Lopes e Macedo (2006), tratava-se da revista, à época, em que as pesquisadoras tiveram maior incidência de artigos de temática curricular. Como os demais periódicos que analisamos na presente pesquisa, não existiam naquele contexto da pesquisa das autoras, podemos inferir que a medida que foram criadas as revistas mais especificamente voltadas ao campo curricular, o periódico Educação e Realidade diminuiu a incidência de artigos dessa natureza.

Concluímos, portanto, que a segunda metade da década pesquisada fornece um aumento significativo no total de produções compiladas, muito em razão da própria ampliação da disponibilidade de edições. Das 226 produções compiladas, buscamos identificar também a distribuição regional dos autores, isto é, compilar o vínculo profissional dos autores para, a partir dessa informação, identificar de que regiões brasileiras os autores são oriundos, a partir da análise de cada periódico. O gráfico abaixo busca essa identificação:

Gráfico 3: Distribuição regional dos autores por periódico

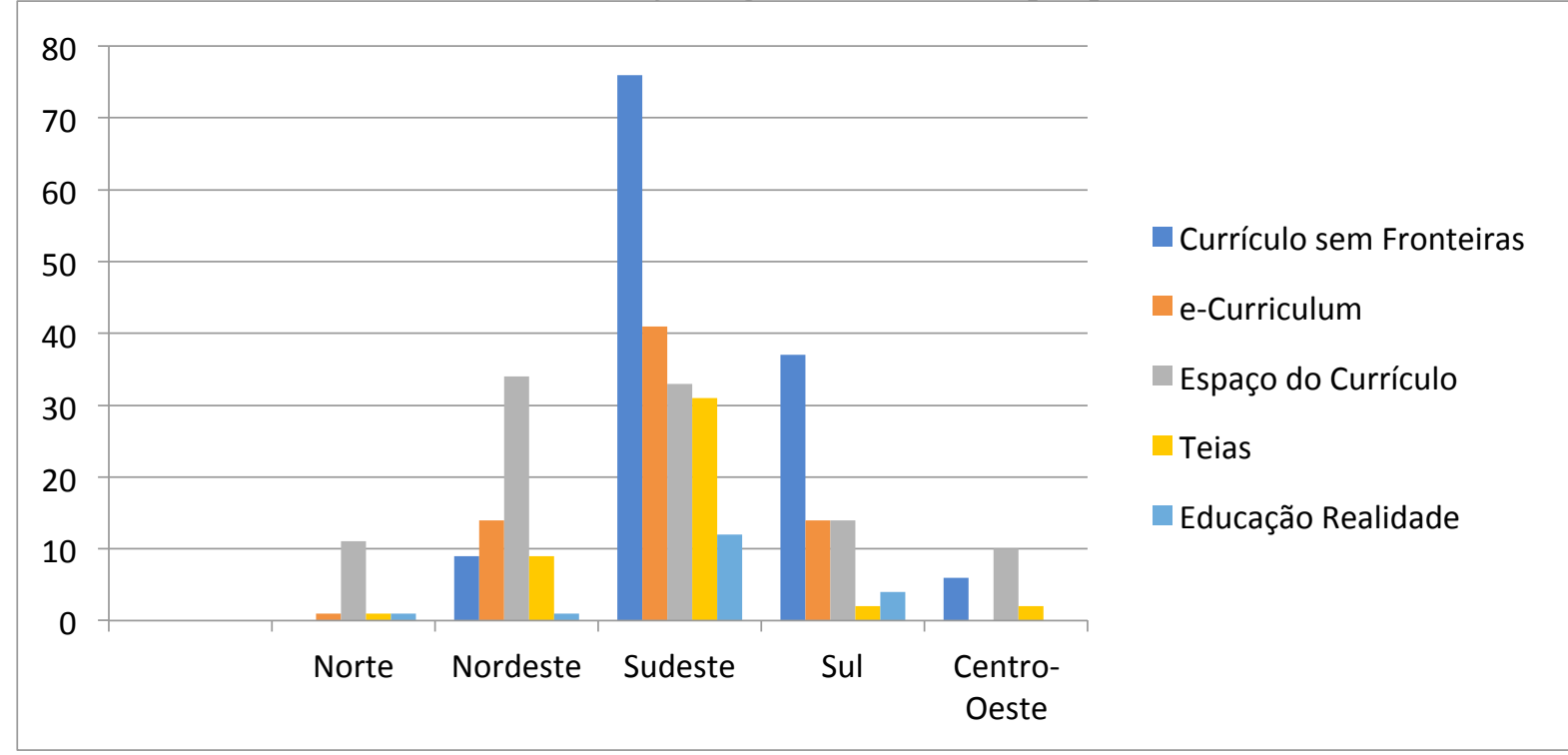

Fonte: dados da pesquisa (2018).

A distribuição regional dos autores evidencia a concentração das produções oriundas de autores vinculados às regiões Sudeste-Sul. De acordo com o Portal da 


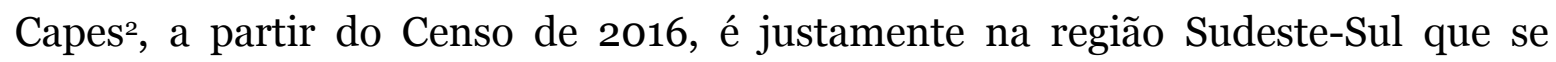
encontra a maior concentração de Programas de Pós-graduação no Brasil, seja no âmbito geral, seja com o filtro das Ciências Humanas. A região Nordeste vem logo depois, seguida da região Centro-Oeste e por último a região Norte. Nesse sentido há uma vinculação intrínseca da distribuição regional dos Programas de Pósgraduação brasileiros com a distribuição regional dos autores dos artigos compilados.

Dos cinco periódicos, o periódico e-Curriculum é vinculado ao Programa de Pós-graduação em Educação da Pontifícia Universidade Católica de São Paulo; o periódico Teias, associado ao Programa de Pós-graduação em Educação da Universidade do Estado do Rio de Janeiro; já o periódico Currículo sem Fronteiras por ser um periódico de pretensão internacional, não se vincula explicitamente a nenhum Programa específico, embora seu conselho editorial é composto majoritariamente por pesquisadores oriundos de Programas de Pósgraduação situados na região Sul. Também na região Sul está vinculado o periódico Educação e Realidade, articulado ao Programa de Pós-graduação em Educação da Universidade Federal do Rio Grande do Sul. A exceção do binômio Sudeste-Sul, portanto, reside na revista Espaço do Currículo, ligada a Universidade Federal da Paraíba.

É perceptível no gráfico, que por ser o único periódico situado fora da concentração Sudeste-Sul, cabe justamente à revista Espaço do Currículo o maior número de produções cujos autores são oriundos de regiões situadas fora do binômio Sudeste-Sul. Há nesse sentido uma relação dos periódicos com seus locais de origem, no tocante às escolhas dos artigos a serem publicados. Em outras palavras, se um periódico se situa em determinada região, a maioria de seus artigos possuem autores oriundos das mesmas regiões pelos quais o periódico é vinculado.

É válido problematizar essa concentração, na medida em que dos 17 pesquisadores dominantes no campo curricular, a ampla maioria também se vincula a programas oriundos da região Sudeste-Sul. Nesse sentido, articulando os 17 pesquisadores dominantes, com a distribuição regional dos periódicos e dos

${ }^{2}$ https://geocapes.capes.gov.br/geocapes/ 
demais autores dos artigos compilados, é perceptível uma concentração significativa da região Sudeste-Sul no tocante a hegemonia da produção curricular brasileira na última década. É mais do que salutar a defesa por uma redução desta concentração em prol de uma maior diversidade regional das produções.

Periódicos fundamentais ao campo, como Currículo sem Fronteiras e $e$ Curriculum, ao longo de dez anos, obtiveram incidência basicamente inexpressiva no tocante às autorias vinculadas às regiões Norte e Centro-Oeste. Mesmo na região Nordeste, esses dois periódicos apresentaram, respectivamente, 4\% e 5,3\% de autores vinculados à região. Coube ao periódico oriundo da região Nordeste (Espaço do Currículo) garantir alguma representatividade e protagonismo, ainda que tímidos, de autores situados em regiões fora da concentração Sudeste-Sul. Somadas as autorias das demais regiões fora do Sudeste-Sul em relação ao total de produções, temos 35,4\%, o que equivale, em certa medida, à proporção também menor de Programas de Pós-graduação em Educação nessas regiões, em comparação ao Sudeste e ao Sul.

Um outro dado interessante, diz respeito à vinculação acadêmica dos autores dos artigos compilados. Foi nossa intenção verificar também essa questão e não somente a distribuição regional dos autores, pois se os periódicos, quase todos, se vinculam à Programas de Pós-graduação específicos, é importante identificarmos de que Programas os autores são oriundos.

Como já observado, há uma relação entre o periódico, seu programa de Pósgraduação e a vinculação regional das produções, ou seja, se um determinado periódico está situado em uma determinada região, a maioria dos artigos compilados terão autores oriundos dessa mesma região. O caso do periódico Espaço do Currículo é ilustrativo; trata-se do único periódico situado na região Nordeste e é justamente nele a maior concentração de artigos cujos autores são oriundos dessa região. O gráfico abaixo ilustra o caso específico do periódico Espaço do Currículo: 
Gráfico 4: Relação entre os autores e os Programas de Pós-Graduação no periódico Espaço do Currículo

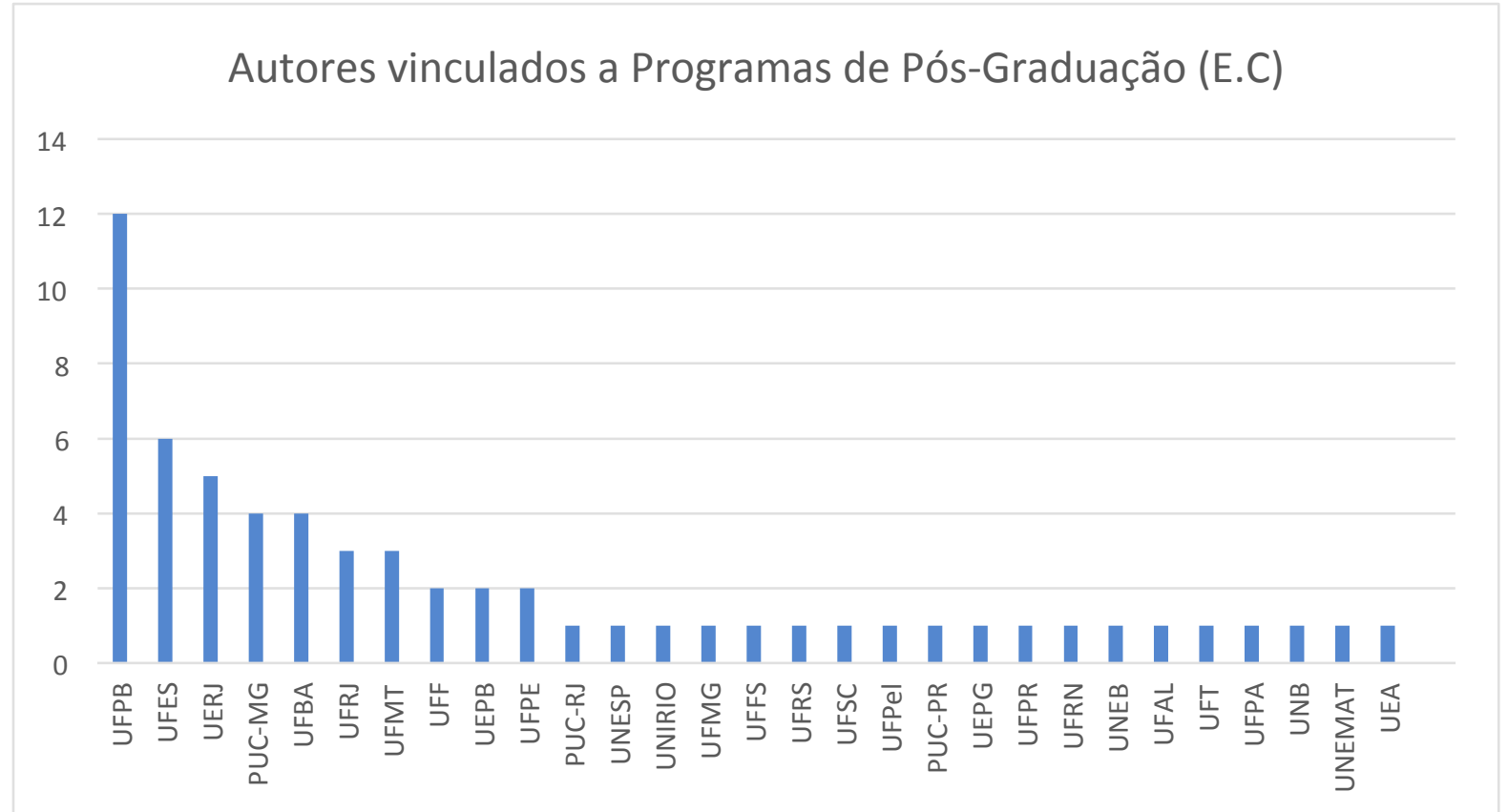

Fonte: dados da pesquisa (2018).

O gráfico evidencia que a maioria das produções compiladas nesse periódico (12) são de autores que se vinculam ao Programa de Pós-graduação da Universidade Federal da Paraíba, situado na região Nordeste, corroborando o dado que comprova que este periódico é justamente o de maior incidência de autores oriundos dessa região. Ademais, este periódico é vinculado justamente a esta universidade, o que demonstra uma relação direta entre o vínculo do periódico com o seu Programa, como fator importante para a publicação no mesmo.

Há uma distância considerável de produções oriundas do Programa da UFPB em relação aos demais, o que demonstra que na última década este periódico optou, propositalmente ou não, não só por autorias da região Nordeste, mas especificamente vinculadas a seu próprio Programa. Esse dado nos motiva a relativizar o gráfico anterior que associa este periódico àquele que mais possibilita autorias ligadas ao Nordeste, pois, conforme pudemos perceber, a questão da região evidenciada, é muito mais devido a uma preferência institucional do que a uma diversificação regional. Tanto que os três Programas subsequentes são oriundos da região Sudeste e só depois, a Universidade Federal da Bahia aparece contemplada com quatro trabalhos. 
O próximo gráfico aborda uma revista com grande incidência de artigos compilados: e-Curriculum.

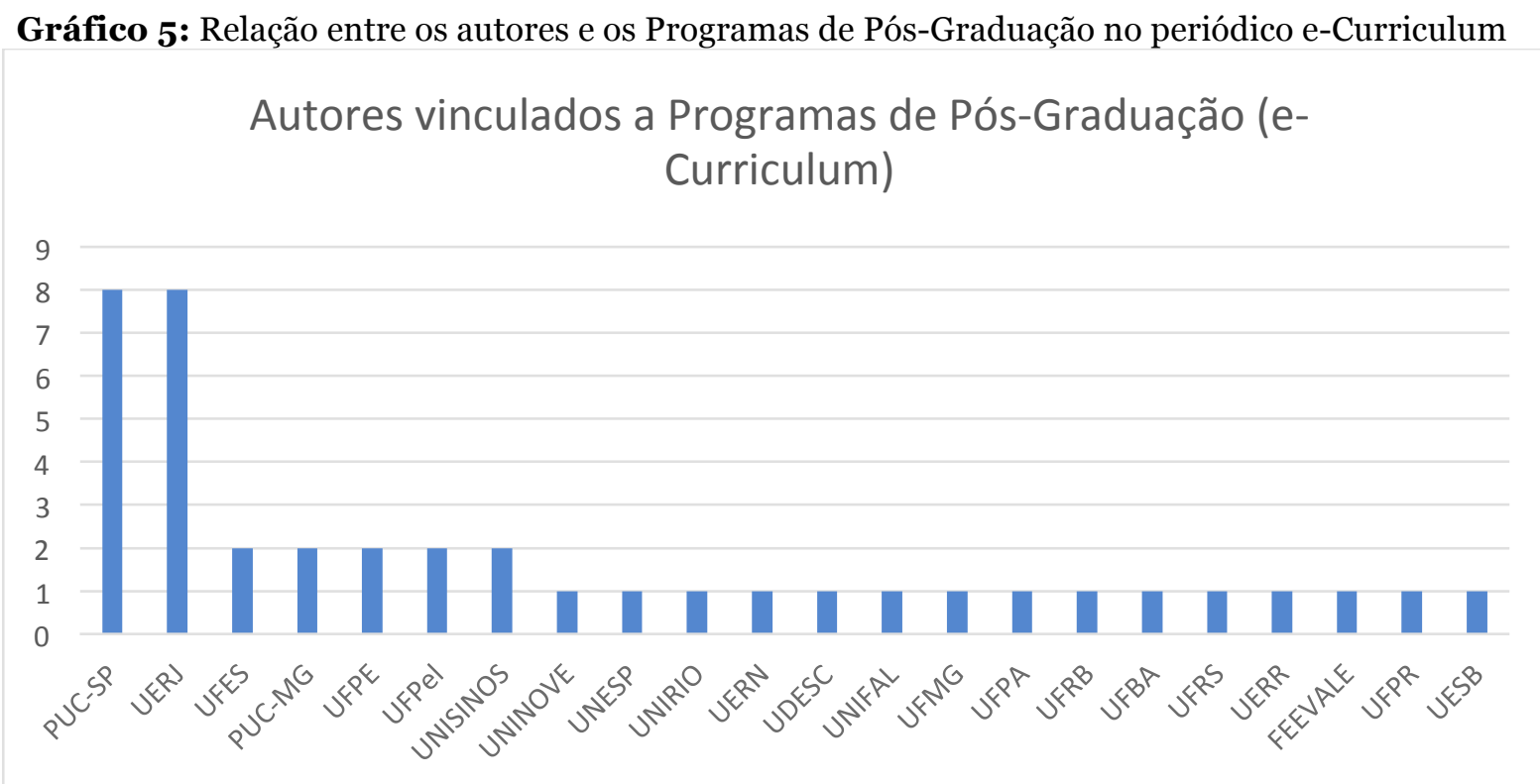

Fonte: dados da pesquisa (2018).

O gráfico referente ao periódico e-Curriculum guarda uma semelhança central em relação ao periódico Espaço do Currículo: em ambos os gráficos, há uma maior incidência de autores vinculados aos Programas que abrigam o próprio periódico. Neste caso, a Pontifícia Universidade Católica de São Paulo através de seu Programa de Pós-graduação em Educação, é o locus primordial de vinculação da maioria dos autores, embora empatado com as produções cujas autorias se vinculam à Universidade do Estado do Rio de Janeiro. Há também uma significativa discrepância em relação aos demais Programas, evidenciando novamente uma certa "preferência" por artigos oriundos do próprio Programa.

É interessante notar que o alto número de produções vinculadas à UERJ se deve especialmente ao editorial de 2014 (v.12, n.3) que tratou da Base Nacional Comum Curricular. Este editorial, em específico, foi coordenado pelas pesquisadoras Elizabeth Macedo, da Universidade do Estado do Rio de Janeiro (UERJ), e Maria Luiza Süssekind, da Universidade Federal do Estado do Rio de Janeiro (UNIRIO). Neste editorial há um salto nas produções vinculadas à UERJ o 
que explica o empate com a PUC-SP, cujas produções, dessa última, estão mais espalhadas entre os anos de 2006-2016.

O próximo gráfico ilustra a situação do periódico Teias, oriundo do Programa de Pós-graduação em Educação da UERJ:

Gráfico 6: Relação entre os autores e os Programas de Pós-Graduação no periódico Teias Autores vinculados a Programas de Pós-Graduação (Teias)

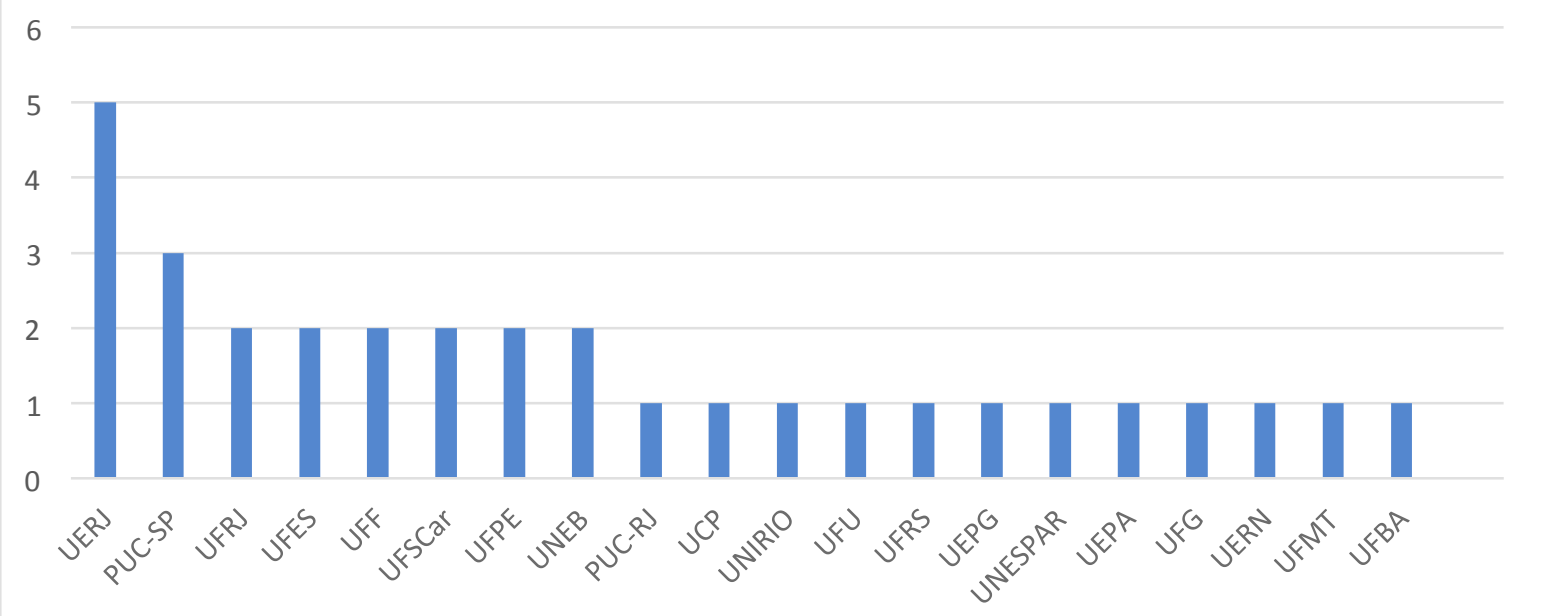

Fonte: dados da pesquisa (2018).

A intrínseca relação entre as autorias dos artigos com os vínculos institucionais de seus autores e o periódico se mantém. A UERJ congrega a maioria das produções compiladas e acolhe o próprio periódico. Há uma incidência significativa de autorias oriundas de Programas situados no Estado do Rio de Janeiro, embora as demais produções, de incidência baixa, congreguem alguma diversidade regional. Assim, como no gráfico referente ao periódico e-Curriculum e ao gráfico relativo à distribuição regional geral, este periódico também concentra especialmente suas produções no Sudeste, embora seja mais diversificado que o periódico e-Curriculum e Educação e Realidade.

Das cinco revistas delimitadas, o periódico Currículo sem Fronteiras, como já dito, não possui uma vinculação direta a um Programa específico de alguma instituição, embora seu conselho editorial seja composto majoritariamente por 
pesquisadores situados em universidades da região Sul. Ademais, trata-se do periódico com maior incidência de artigos compilados pela pesquisa.

O caso deste periódico é especialmente interessante justamente pelo fato dele não representar uma continuidade do que temos até aqui observado: a relação direta entre o periódico, o Programa que o acolhe, e o vínculo da maioria das produções. Como esta revista não se vincula diretamente a nenhum Programa, nossa hipótese era de que as produções seriam mais espalhadas, fazendo jus ao termo "sem fronteiras".

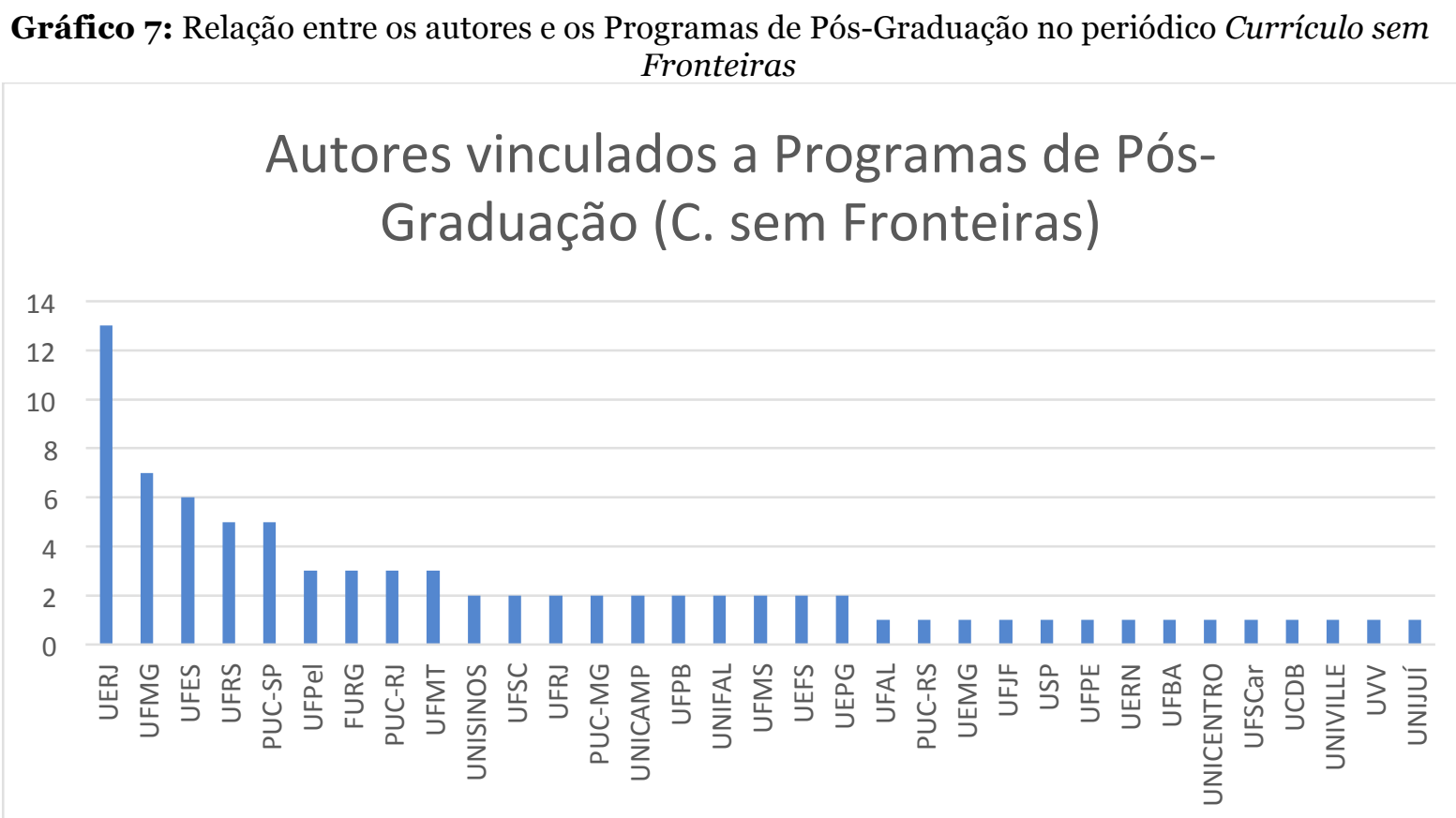

Fonte: dados da pesquisa (2018).

Conforme nossa hipótese, este periódico simboliza, em comparação aos outros, a maior pluralidade em relação aos vínculos institucionais dos autores. Há uma significativa e emblemática predominância de produções oriundas da UERJ em relação às demais, que se dividem posteriormente, entre universidades situadas especialmente na regional Sudeste-Sul. Dos dez primeiros Programas, apenas a Universidade Federal do Mato Grosso foge a esta regra.

Podemos observar também uma incidência alta de produções vinculadas às instituições situadas no Rio Grande do Sul; algumas delas, de inexpressiva 
incidência nos gráficos anteriores, aparecem agora com maior destaque, tais como: Universidade Federal do Rio Grande do Sul (UFRS), Universidade Federal de Pelotas (UFPel), Universidade Federal do Rio Grande (FURG) e Universidade do Vale dos Sinos (UNISINOS). Neste caso, podemos inferir alguma relação entre esse dado e o que já dissemos a respeito do Conselho Editorial do periódico ser composto predominantemente por pesquisadores situados na região Sul.

Entretanto, não se pode negar o predomínio das autorias vinculadas à UERJ, que sempre esteve permeada por alta incidência nos periódicos analisados. O gráfico abaixo traz um levantamento total dessas produções, somados todos os periódicos, para que possamos ter uma noção mais geral da representatividade dessas instituições na distribuição regional das produções.

Gráfico 8: Total das produções e seus Programas de Pós-graduação.

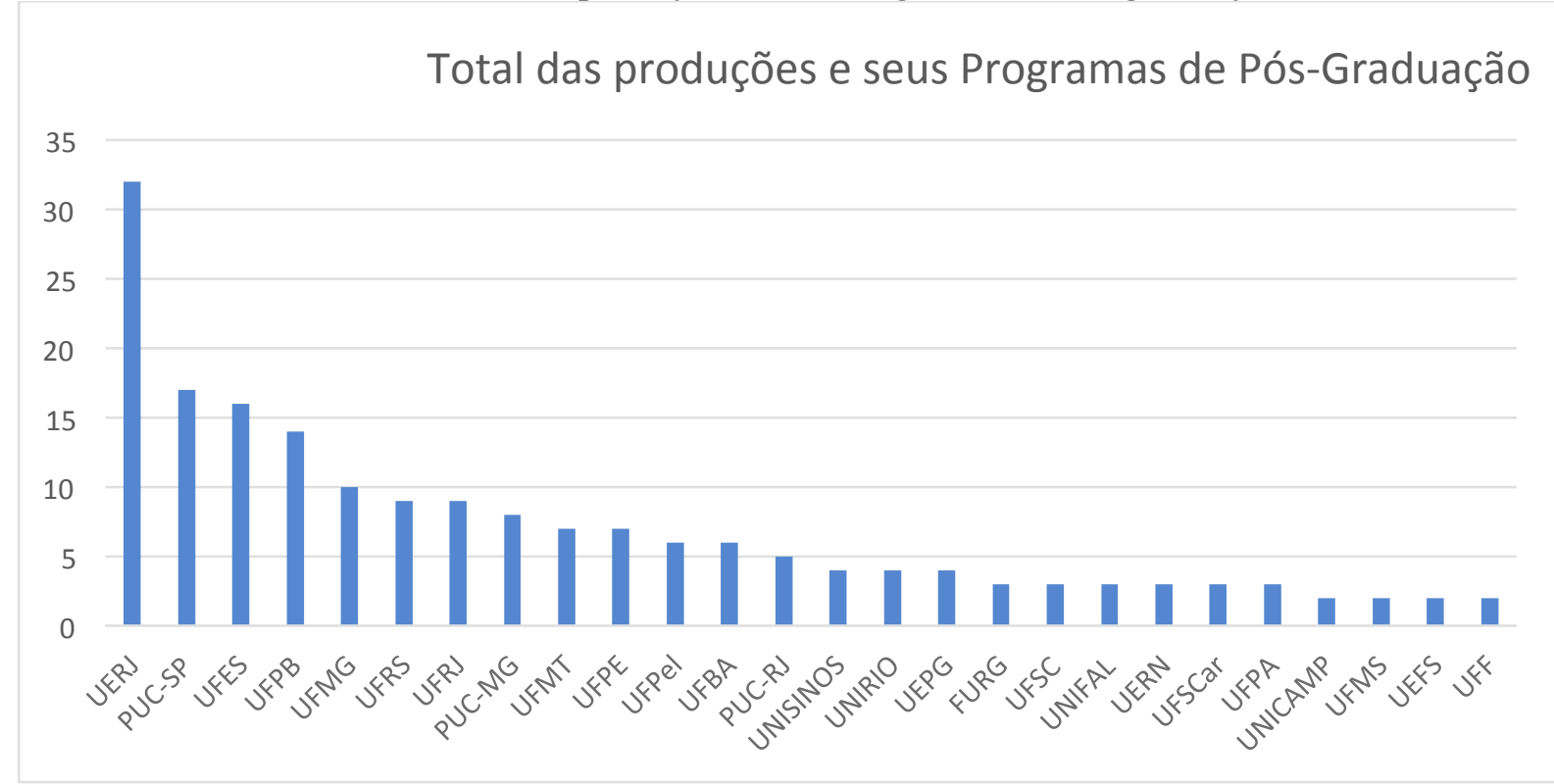

Fonte: dados da pesquisa (2018).

O desempenho da UERJ salta imediatamente aos olhos quando nos deparamos com o gráfico geral das produções e as vinculações aos Programas. A instituição corresponde a mais da metade da instituição segunda colocada (PUCSP). Tal desempenho não se deve, certamente, ao acaso. Além do próprio mérito da instituição, em se tornar tão produtiva para o campo curricular brasileiro e 
conseguir emplacar artigos em periódicos cruciais ao campo, outros fatores ajudam a entender esse destaque.

Para compilar os referenciais bibliográficos de todas as produções, adotamos os seguintes critérios: primeiramente, todas as obras seriam compiladas e inseridas em um banco de dados. Num segundo momento, separamos as obras em três categorias: a) referências centrais ao currículo; b) referências clássicas ${ }^{3}$ que permearam a discussão curricular; c) demais referências que não estabeleciam relação direta com a discussão curricular. Dessas três, traremos a primeira para que possamos inferir mais pistas a respeito da constituição do campo curricular brasileiro na última década.

Fazer essa compilação nos impôs uma série de desafios: logo percebemos que alguns artigos citavam várias obras de um mesmo autor, entretanto, no corpo do artigo, citava apenas uma vez as referidas obras. Nesses casos, como contabilizar? Em outros casos, um determinado autor cita a si mesmo em vários momentos; e nesses casos, como compilar? Essas e outras dúvidas pairaram sob esta pesquisa e nos obrigou a fazer uma escolha, certamente, não imune a críticas e ressalvas. Optamos por contabilizar cada referência como um voto, ou seja, se determinado artigo utilizou cinco livros de Deleuze, este autor recebeu cinco votos, e suas respectivas obras foram compiladas. Desse modo, mesmo sabendo que referenciar vários livros do autor, não necessariamente significa citá-lo em grande quantidade no corpo do texto, ainda assim optamos por valorizar cada bibliografia utilizada, entendendo que ela, de algum modo, norteou aquela produção do autor, explicitamente ou implicitamente. Assim, padronizamos o critério de computar um voto para cada bibliografia referenciada, independente se o autor citava a si mesmo no trabalho.

Outra informação importante diz respeito aos livros escritos por um ou mais autores; nestes casos, cada autor também recebeu individualmente seu voto. Isso foi comum entre os autores Gilles Deleuze e Félix Guattari; Alice Casimiro Lopes e Elizabeth Macedo; Tomaz Tadeu Silva e Antônio Flávio Barbosa Moreira. Esses

3 Entendemos por clássico, conforme Saviani (2003, p.18): “Clássico, em verdade, é o que resistiu ao tempo. É neste sentido que se fala na cultura greco-romana como clássica, que Kant e Hegel são clássicos da filosofia, Victor Hugo é um clássico da literatura universal”. 
autores escreveram juntos obras importantes ao campo curricular e que foram muito referenciadas nas produções compiladas. Como dito, nesses casos, a cada autor foi computado um voto.

Compilamos os referenciais bibliográficos dos cinco periódicos separadamente, dividindo entre a primeira e a segunda metade da década delimitada. A intenção era verificar se havia alguma diferença substancial entre os periódicos, mas não foi o que ocorreu. Nesse sentido, optamos por trazer o compilado total dos referenciais bibliográficos, somados todos os periódicos e no período total de 2006-2016: 
Gráfico 9: Referenciais bibliográficos dos cinco periódicos compilados (2006-2016)4

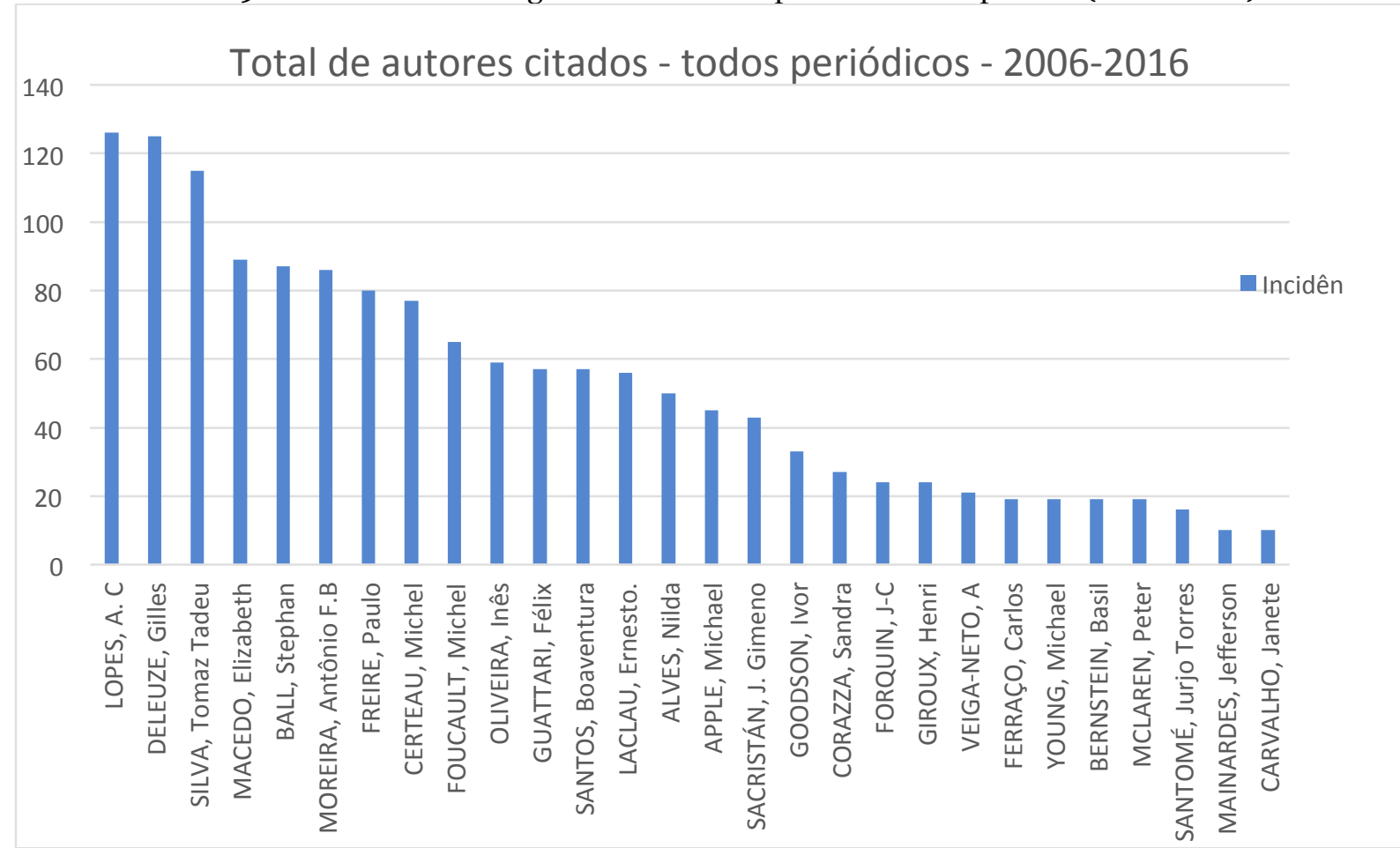

Fonte: dados da pesquisa, (2018).

Os dez primeiros autores elencados como referenciais bibliográficos mais utilizados no total dos artigos compilados, nos mostram, num primeiro momento, uma diversidade de abordagens e algumas curiosas conclusões: dos dez primeiros, existem quatro estrangeiros (Deleuze, Ball, Certeau e Foucault) que não são propriamente do campo curricular. Mas os seis brasileiros que completam a listagem dos dez iniciais, exceção à Paulo Freire, são todos curriculistas, embora Paulo Freire como já dito em capítulos anteriores, é certamente o precursor dos estudos em currículo no Brasil numa linhagem crítica (MOREIRA, 1990, 1998).

Se observarmos os autores brasileiros presentes no gráfico anterior, é possível perceber que apenas um não faz parte do grupo dos 17 pesquisadores dominantes do campo: trata-se de Jefferson Mainardes; geralmente muito citado nos artigos que envolvem a relação do currículo com a organização em ciclos, esse

4 Referenciais cujas citações ocorreram menos de dez vezes foram retirados do gráfico. A título de exemplo, citamos: Roberto Sidnei de Macedo, Maria Luiza Süssekind, Antônio Carlos Amorim, Miguel Arroyo, Marlucy Paraíso, Marisa Vorraber Costa. 
autor ficou à frente de outros autores que compõem o grupo dos pesquisadores dominantes.

Nos parágrafos anteriores, mencionamos a centralidade e a liderança da UERJ no tocante às produções compiladas e os vínculos institucionais de seus autores. O gráfico acima fortalece nossa conclusão na medida em que a liderança dos referenciais é de uma pesquisadora da UERJ, e dos seis primeiros referenciais brasileiros, metade são de pesquisadores pertencentes a essa instituição. Dos referenciais brasileiros presentes no gráfico, ao todo, há uma predominância da UERJ com quatro pesquisadoras (Alice C. Lopes, Elizabeth Macedo, Inês B. Oliveira e Nilda Alves).

Uma leitura apressada argumentaria que a presença notável de Alice Casimiro Lopes e Elizabeth Macedo na lista dos referenciais das produções, se explica pela maciça produção de ambas nos últimos anos. Ao todo, no recorte temporal utilizado no trabalho, as duas produziram mais de 35 artigos específicos sobre currículo, sem contar apresentações em congresso e livros. Contudo, a vasta produção, inclusive diversas vezes em parceria, não explica unicamente a representatividade e a influência consolidadas. Pois alguns pesquisadores de produção volumosa na década, como Marlucy Paraíso, por exemplo, não constam sequer no gráfico acima.

Com isso, mais uma vez remetemos à conclusão de que a UERJ se consolida como um polo irradiador de construção hegemônica ao campo, sob a predominância de Elizabeth Macedo e Alice C. Lopes, que por sua vez, auxiliam no fortalecimento da temática das políticas de currículo - tema preferencial das autoras - e também contribuem para enfatizar a importância de Stephen Ball e Ernesto Laclau, ambos autores muito utilizados pelas duas curriculistas e por demais autores que trabalham as políticas de currículo sob balizamento teórico das pesquisadoras da UERJ. Somado a isso, ambas produziram também considerável número de artigos teóricos, o que torna ainda mais plural suas produções abarcando número ainda maior de leitores.

Falando especificamente da liderança de Alice C. Lopes, é válido ressaltar que a autora teve abarcada diversas obras o que torna impossível dizer que dentro 
de sua vasta produção, existam uma ou duas predominantes. Houve um notável equilíbrio entre seus livros, capítulos de livro e artigos, de modo que podemos concluir que a produção da autora atende a diversos interesses no campo curricular, e se caracteriza por uma pluralidade e qualidade, que acaba por ser útil a artigos que discutem políticas de currículo, teorias curriculares, ensino de Ciências, hibridismo, cultura e conhecimento.

Em nosso entendimento, o gráfico deve ser compreendido através de quatro subgrupos que representam graus distintos de influência. O primeiro corte deve ser feito nos três primeiros, Alice C. Lopes, Gilles Deleuze e Tomaz Tadeu Silva. Estes três primeiros estão em uma distância considerável dos demais, constituindo-se assim como as três grandes referências bibliográficas do campo curricular brasileiro na última década. O segundo corte abarca de Elizabeth Macedo até Michel de Certeau e também se constitui como referências de grande impacto no campo, mas com alguma distância tanto em relação aos três primeiros, quanto aos demais.

O terceiro corte, de influência razoável, compreende de Michel Foucault até Gimeno Sacristán. Neste corte há uma variedade maior de linhagens teóricas em relação aos anteriores. O último corte, de influência mediana, que se estende de Félix Guattari à Janete Carvalho, abarca maior número de teóricos, com incidências parecidas, quase lineares e abarca a maior variedade de tendências. Há uma predominância de teóricos vinculados às concepções pós-críticas, especialmente entre os dez primeiros, ficando os referenciais críticos mais alinhados aos subgrupos de influência mediana e razoável, exceção à Antônio Flávio Barbosa Moreira, representante da vertente curricular crítica presente entre os dez primeiros mais citados.

Junto à Alice Casimiro Lopes, temos um filósofo que nunca tratou de currículo propriamente dito em suas obras e pouco abordou a temática da educação. Compartilhamos as problematizações feitas por Caffagni (2017, p. 10), que aponta Gilles Deleuze como um filósofo que embora aborde temas educacionais em sua obra, não é propriamente um teórico da educação. 
Deleuze e Guattari não dedicaram obras completas a educação. Em várias passagens, os estudiosos discorrem sobre docência, aprendizagem ou sobre a escola. Entretanto, a filosofia tratada por eles está longe de conter uma teoria da educação. Até onde pudemos averiguar, não encontramos nenhuma aplicação prática sistemática de suas teorias em um sistema pedagógico; poderíamos tão somente dizer, e com alguma licença poética, que seu pensamento dialoga com algumas práticas aqui e acola. Qual e então a razão que leva pesquisadores a estudar a influência desses autores na educação?

Complementando a pergunta feita por Caffagni (2017) ao final da citação acima, poderíamos indagar: quais razões levam autores do campo curricular a se balizarem por esses autores em suas produções? Entendemos que é possível que determinados autores, ainda que não tenham priorizado e aprofundado especificamente sobre a temática educacional, devido a originalidade, penetração e legitimidade de sua obra, acabam tendo muito a dizer ao campo educacional. Karl Marx certamente é um exemplo disso na perspectiva crítica. Podemos dizer, que na perspectiva pós-estruturalista, Gilles Deleuze é este pensador que, no campo do currículo, tem oferecido insights aos autores do campo, especialmente nas produções que operam na perspectiva da filosofia da diferença.

Percebemos algo curioso ao compararmos a incidência das citações às obras de Alice C. Lopes e Gilles Deleuze. No caso do filósofo francês, geralmente os artigos que o utilizam, costumam citar diversas de suas obras em um mesmo artigo. É comum o uso de pelo menos três a quatro livros por produção. Diferente da pesquisadora da UERJ que tem média de duas referências por produção. Isso significa que se pegarmos somente o número de obras, teremos mais produções citando a pesquisadora do que o pensador pós-estruturalista. Um exemplo disso são os artigos de Carvalho (2016) que cita onze livros de Gilles Deleuze em seu trabalho e Aspis (2016) que cita oito obras do pensador francês. Estes dois exemplos nos ajudam a perceber que há um número menor de artigos que o citam em comparação à Alice C. Lopes, mas como nosso critério foi pontuar a cada referencial listado, alguns artigos renderam várias pontuações à Deleuze.

Os trabalhos que utilizaram Gilles Deleuze compõem-se basicamente de dois tipos: estudos do cotidiano, especialmente no viés dos pesquisadores cotidianistas da UFES e produções de caráter teórico que focalizam a diferença associando-a à 
criação, o agenciamento do desejo, o rizoma, a transgressão, não raramente, calcadas em produções que flertam com a abstração hermética de difícil entendimento (CORAZZA, 2010), (OLEGÁRIO, CORAZZA, 2015), (ASPIS, 2016), (AMORIM, 2013).

Percebemos então, que tanto em nossa pesquisa, quanto na tese de Caffagni (2017), a centralidade de Deleuze é notória. O autor chega a ultrapassar, em termos de referenciais bibliográficos, dois dos autores mais notórios do campo, como Tomaz Tadeu Silva e Antônio Flávio B. Moreira. É extremamente significativo tal constatação, especialmente se voltarmos ao gráfico e verificarmos que os dois curriculistas brasileiros possuem alta incidência, ou seja, não quer dizer que foram esquecidos ou negligenciados, e sim, que Deleuze tem oferecido subsídios teóricos em abundância para as produções em currículo.

Outra conclusão extraída de Caffagni (2017) que é idêntica ao que percebemos em nossa pesquisa, trata-se das obras mais citadas de Deleuze. Em nossa pesquisa, respectivamente as quatro obras mais citadas foram: Mil Platôs, $O$ que é Filosofia? Diferença e Repetição e Diálogos. Exatamente as obras de maior incidência na tese de Caffagni (2017) que não se limitou, como já dito, ao campo do currículo em sua análise. Tais conclusões demonstram que as quatro referidas obras são as que mais têm respaldado os autores que desejam operar com a filosofia deleuziana no tocante às produções com temática curricular.

A alta incidência das obras Mil Platôs e $O$ que é filosofia? escritas em parceria por Deleuze e Guattari, nos faz refletir a respeito da apropriação destes autores no campo do currículo, especialmente porque esses dois livros constituem uma das partes mais densas e volumosas da contribuição dos dois filósofos franceses. Nestas obras são desenvolvidos alguns conceitos notáveis desenvolvidos pela dupla. Cabe mencionar que nas obras citadas, especialmente em Mil Platôs, Deleuze e Guattari discutem uma infinidade de assuntos a partir de abordagens pouco convencionais, apresentando um alto grau de experimentação, inovação estética e científica, que transgridem a todo momento o modo mais tradicional como os livros acadêmicos se constituem. 
Alice C. Lopes, Deleuze e Tomaz Tadeu Silva formam um primeiro eixo de referenciais bibliográficos, no sentido de que estão a alguma distância dos demais autores. Parceira de Alice C. Lopes em diversos trabalhos, a quarta referência mais citada foi Elizabeth Macedo. Acerca desse dado, é necessário ressaltar que a maioria das citações a esta autora se deveu aos trabalhos em parceria com Alice C. Lopes. As obras em parceria mais citadas foram: Contribuições de Stephen Ball para o estudo das políticas de currículo, capítulo do livro de Jeferson Mainardes (Políticas educacionais: questões e dilemas); e o livro Teorias de Currículo. Isoladamente, Elizabeth Macedo foi predominantemente citada através de seus artigos que focalizam a Base Nacional Comum Curricular, embora seus diversos outros artigos em maior ou menor grau, foram lembrados.

A quinta referência de maior incidência, Stephen Ball, possui umbilical relação com a significativa presença de Alice C. Lopes e Elizabeth Macedo. Como já dito, há nas produções, uma predominância da UERJ no campo curricular brasileiro, locus das duas curriculistas citadas, que têm trabalhado, predominantemente com a temática das políticas de currículo a partir da influência central de S. Ball e Ernesto Laclau. Nesse sentido, tanto as duas curriculistas, bastante produtivas, e as demais produções que se amparam nelas, acabam caindo também nas concepções fundantes de S. Ball a respeito das políticas de currículo. Não é exagero dizer que toda produção que cita o autor inglês, trata da temática das políticas de currículo. Nesse ponto, não há pluralidade, e sim, uma coesão temática entre o autor e as produções.

Antônio Flávio Barbosa Moreira, a sexta referência mais citada no total das produções, é juntamente com Tomaz Tadeu Silva, um expoente no campo do currículo no Brasil. Por si só, isso ajuda a explicar a alta incidência de ambos. $\mathrm{O}$ fato de Tomaz Tadeu estar à frente, no nosso entendimento, se deve a dois fatores: o primeiro, à obra de Tomaz Tadeu (Documentos de Identidade. Uma introdução às teorias de currículo) que se tornou clássica no campo e que balizou, como já dito, diversas produções no tocante a aspectos introdutórios das vertentes curriculares por ele categorizadas. 
O segundo fator, conseguimos inferir a partir do conjunto dos dados. Olhando os referenciais mais citados, e no conjunto das temáticas e conceitoschave das produções, que iremos analisar de forma mais profunda mais adiante, conseguimos perceber uma inclinação pós-crítica no campo curricular brasileiro. $\mathrm{O}$ gráfico anterior ajuda a ilustrar essa questão trazendo uma maioria de autores de linhagem pós-crítica. Ademais, dos 17 pesquisadores dominantes do campo, a maioria também possui viés pós-crítico, e como se verá mais adiante, o mesmo ocorre com as produções compiladas. Tudo isso ajuda a entender o motivo pelo qual Antônio Flávio B. Moreira, embora muito citado, está atrás de Tomaz Tadeu Silva, na medida em que Antônio Flávio é um expoente da concepção curricular crítica, ao contrário de Tomaz Tadeu. Assim, interpretamos que a diferença entre os dois, no âmbito dos referenciais bibliográficos, reside justamente em uma incidência maior de trabalhos de corte pós-moderno e pós-estrutural no campo curricular brasileiro, e que por essa razão, utilizam autores deste viés, o que os aproxima mais de Tomaz Tadeu do que de Antônio Flávio B. Moreira.

Ainda assim, Antônio Flávio Barbosa Moreira possui grande incidência de citações, especialmente suas obras de caráter histórico e/ou pesquisas que analisam os desdobramentos e concepções de vertentes curriculares (MOREIRA, 1990, 1998, 2001). Artigos que enfatizaram a temática do conhecimento também citaram abundantemente os trabalhos de Antônio Flávio, que tem se notabilizado ao longo de suas produções, como um curriculista crítico defensor da centralidade do conhecimento para o campo do currículo (MOREIRA, 2002, 2003, 2007, 2012); (MOREIRA e CANDAU, 2008); (MOREIRA e MELGAÇO-JÚNIOR, 2017). Em parceria com Tomaz Tadeu Silva, ainda na década de 90, a obra Currículo Cultura e Sociedade também foi bastante referenciada.

Paulo Freire, o precursor da teoria crítica curricular brasileira é o sétimo colocado no tocante aos referenciais bibliográficos e grande parte desta alta incidência deve-se ao periódico e-Curriculum. Este periódico é tão decisivo na alta incidência de Paulo Freire que, nas demais revistas, no total das produções, Gilles Deleuze e Alice C. Lopes se alternavam como as referências mais citadas. Porém, na e-Curriculum Paulo Freire foi o teórico de maior incidência, seguido por Inês 
Barbosa de Oliveira, Michel Foucault e somente na quarta colocação, Alice C. Lopes; Gilles Deleuze obteve inexpressiva incidência.

É bastante curioso identificar essa peculiaridade da revista $e$-Curriculum no tocante à baixa incidência de Deleuze e outros filósofos pós-estruturalistas. Por outro lado, não surpreende a alta incidência de Paulo Freire, pois, como já observado em gráficos anteriores, há uma relação direta dos autores das produções e seus vínculos institucionais oriundos da instituição da qual a revista é vinculada. Não é diferente com esse periódico, pertencente ao Programa da PUC-SP, que conta com a Cátedra Paulo Freire, sob liderança de Ana Maria Saul e outros pesquisadores que também produzem trabalhos voltados ao currículo sob influência central da obra freireana. É mais um dado que se interpretado com os outros, fornece subsídios para entendermos a ideia de uma rede de produções, vínculos institucionais e temáticas predominantes, que se fortalece através de mecanismos de legitimidade que simbolizam o modo pelos quais as regras do jogo se consolidam no campo (BOURDIEU, 1983).

De certo modo, a lista dos referenciais mais citados demonstra a pluralidade do campo curricular. Diferentes vertentes podem ser observadas, não só entre perspectivas críticas e pós-críticas, mas internamente entre as próprias perspectivas. No entanto, em meio aos referenciais de maior incidência, pensando nos quinze primeiros nomes presentes no gráfico, observa-se um leve predomínio de autores de linhagem pós-moderna e pós-estrutural, em detrimento daqueles de tradição crítica.

É notável, então, a baixa ocorrência de autores oriundos das vertentes curriculares críticas, especialmente daqueles teóricos críticos em diálogo, que contribuíram de forma decisiva ao campo curricular brasileiro a partir da década de oitenta: Michael Apple, Henry Giroux e Peter McLaren.

\section{CONSIDERAÇÕES FINAIS}

Procuramos estabelecer um quadro mais geral, quantitativo, fornecendo ao leitor uma noção ampla das 226 produções compiladas entre 2006 e 2016. 
Constatamos, especialmente se compararmos à pesquisa de Lopes e Macedo (2006), um aumento significativo das produções, fruto da criação de novas revistas que não existiam no período pesquisado pelas autoras e resultante também do aumento das edições desses periódicos.

Foi possível perceber um predomínio de referenciais bibliográficos de linhagem teórica pós-crítica no total das produções, o protagonismo de Alice Casimiro Lopes e Gilles Deleuze como referenciais bibliográficos do total das produções, a concentração regional das produções em torno do Sudeste e do Sul, uma característica endógena da maioria dos periódicos selecionados, a centralidade da UERJ como polo irradiador da produção curricular brasileira; um enfraquecimento da influência das vertentes curriculares críticas nos artigos compilados.

A pesquisa acredita contribuir, nesse recorte estabelecido, para reflexões acerca dos desdobramentos do campo curricular brasileiro e estimula novas pesquisas, a partir de novos recortes e critérios, que lançem seus olhares a respeito da produção quantativa do campo.

\section{REFERÊNCIAS}

AMORIM, Antônio Carlos. Três crianças a compor um plano para o currículo. Currículo sem Fronteiras, v. 13, p. 411-426, 2013.

ASPIS, Renata. Notas esparsas sobre filosofias da diferença e currículos.

Currículo sem Fronteiras, v. 16, n. 3, p. 429-439, 2016.

BARDIN, Laurence. Análise do conteúdo. Tradução: Luis Antero Reto. São Paulo: Edições 70, 2011.

BOURDIEU, Pierre. Questões de Sociologia. Rio de Janeiro: Marco Zero, 1983.

CAFFAGNI, Lou Guimaraes Leão. Entre Deleuze, Guattari e o currículo: uma cartografia conceitual (2000- 2015). 2017. 391 f. Tese (Doutorado) - Faculdade de Educação, Universidade de São Paulo, São Paulo, 2017.

CARVALHO, Janete Magalhães. Desejo e Currículos e Deleuze e Guattari e... Currículo sem Fronteiras, v. 16, n. 3, p. 440-454, set./dez. 2016. 
CHIZZOTTI, Antônio. Pesquisa qualitativa em ciências humanas e sociais. Petrópolis/RJ: Vozes, 2008.

CORAZZA, Sandra. Os sentidos do currículo. Revista Teias, v. 11, n. 22, p. 149-164, maio/agosto 2010.

CORAZZA, Sandra.; OLEGÁRIO, Fabiane. Entre raízes e radículas. O que se passa no currículo escolar. Espaço do Currículo, v.8, n.3, p. 356-363, 2015.

GIL, Antônio Carlos. Como elaborar projetos de pesquisa. 4. ed. São Paulo: Atlas, 2002.

LOPES, Alice Ribeiro Casimiro; MACEDO, Elizabeth. Currículo da educação básica (1996-2002). Brasília: Ministério da Educação, Instituto Nacional de Estudos e Pesquisas Educacionais Anísio Teixeira, 2006.

MOREIRA, Antônio Flávio Barbosa. Currículos e programas no Brasil. Campinas: Papirus, 1990.

MOREIRA, Antônio Flávio Barbosa. A configuração atual dos estudos curriculares: a crise da teoria crítica. In: PARAÍSO, Marlucy. (Org.). Antonio Flavio Barbosa Moreira: pesquisador em curriculo. Belo Horizonte: Autentica,. p. 95-115, 1998.

MOREIRA, Antônio Flávio Barbosa. A recente produção científica sobre currículo e multiculturalismo no Brasil (1995-2000); avanços, desafios e tensões. Revista Brasileira de Educação, Campinas, n.18, p.66-81, 2001.

MOREIRA, Antonio Flavio Barbosa. Currículo, diferença cultural e diálogo. Educação \& Sociedade, ano XXIII, n. 79, p.15-37, 2002.

MOREIRA, Antonio Flavio Barbosa. O campo do currículo no Brasil: os embates e os desafios em sua construção no espaçotempo da ANPEd. Revista de Estudos Curriculares, v. 1, n. 1, p. 33-57, 2003.

MOREIRA, Antônio Flávio Barbosa. A Importância do conhecimento escolar em propostas curriculares alternativas. Educação em Revista, Belo Horizonte, v. 45, p. 265-290, jun. 2007.

MOREIRA, Antônio Flávio Barbosa. CANDAU, Vera Maria. Currículo, conhecimento e cultura. In: Indagações sobre currículo. Brasília: Ministério da Educação, Secretaria de Educação Básica, p.17-34, 2008.

MOREIRA, Antônio Flávio Barbosa. A produção de conhecimento na área de currículo e repercussões na qualidade da escola pública. XVI ENDIPE Encontro Nacional de Didática e Práticas de Ensino - UNICAMP - Campinas 2012. 
MOREIRA, Antônio Flavio Barbosa.; MELGAÇO, Paulo da Silva Júnior.

Conhecimento escolar nos currículos das escolas públicas: reflexões e apostas.

Currículo sem Fronteiras, v. 17, n. 3, p. 489-500, 2017.

Sobre o autor

Márden de Pádua Ribeiro. Graduado em História. Especialista do Bernoulli

Sistema de Ensino. Mestrado e doutorado em Educação pela Pontifícia Universidade Católica de Minas Gerais. E-mail: mardendepadua@yahoo.com.br 